УДК 908

https://doi.org/10.36906/2311-4444/21-3/08

Пузанов В.Д.

Puzanov V.D.

РУССКАЯ АРМИЯ В СИБИРИ В 30-50 ГОДЫ ХVIII в.

\title{
THE RUSSIAN ARMY IN SIBERIA IN THE 30-50 YEARS OF THE XVIII CENTURY
}

Аннотация. Военные реформы Петра I привели к формированию регулярных полков Сибири. При Петре I русской регулярной кавалерией стали драгунские полки. При Петре I драгунские полки были единственным видом русской регулярной кавалерии. В русской полевой армии Петр I сформировал 34 драгунских полка. Кроме того, гарнизонные драгунские полки были сформированы в центрах губерний в стратегически важных городах Азове, Астрахани, Казани, Тобольске. В 30-50 гг. XVIII в. количество полевых драгунских полков Российской империи уменьшилось до 20. В 1744 г. в Сибирь для защиты края от джунгар были посланы 3 полевых драгунских полка Олонецкий, Вологодский и Луцкий, и 2 полевых пехотных полка Ширванский и Нашебургский. По указу Сената от 29 сентября 1744 г. все русские войска Сибири были подчинены главному командиру Сибирского корпуса, который подчинялся Военной коллегии. Главным командиром в Сибири был назначен генерал-майор Христиан Киндерман. В марте 1756 г. в русской армии состояли 3 кирасирских, 29 драгунских и 46 пехотных всего 78 армейских полков, в которых имелось 172440 чел. В итоге во время Семилетней войны число полевых драгунских частей России уменьшилось в 3 раза и к 1763 г. составляло всего 7 полков. В результате, если в 1754 г. драгуны составляли 36627 человек $(92,6 \%)$, то к 1767 г. в их рядах насчитывалось только 4802 человек $(12,8 \%)$ от русской кавалерии.

Ключевые слова: драгуны, солдаты, кавалерия, линия, кочевники, Сибирский корпус.

Сведения об авторе: Пузанов Владимир Дмитриевич, д-р ист. наук, Шадринский государственный педагогический университет, г. Шадринск, Россия, alan1971@bk.ru
Abstract. The reforms of Peter I became the basis for the gradual restructuring of all the military forces of Siberia. The main role in the Russian military cavalry of the Peter's era was played by dragoons. Under Peter I, dragoon regiments were the only type of Russian regular cavalry. In the field army, Peter I ordered the formation of 34 dragoon regiments. In addition, garrison dragoon regiments were formed in the province in the strategically important cities of Azov, Astrakhan, Kazan, and Tobolsk. In the 30-50s of the XVIII century, the number of field dragoon regiments of the Russian Empire decreased to 20. In 1744, 3 field dragoon regiments Olonetsky, Vologda and Lutsk, and 2 field infantry regiments Shirvan and Nasheburg were sent to Siberia to protect the region from the Dzungars. By the decree of the Senate of September 29, 1744, all the Russian troops of Siberia were subordinated to the chief commander of the Siberian Corps, who was subordinate to the Military College. Major-General Christian Kinderman was appointed the main commander in Siberia. In March 1756, the Russian army consisted of 3 cuirassiers, 29 dragoons, and 46 infantry regiments, totaling 78 army regiments, with 172,440 men. As a result, during the Seven Years ' War, the number of field dragoon units in Russia decreased by 3 times and by 1763 was only 7 regiments. As a result, if in 1754 the dragoons were 36,627 people $(92.6 \%)$, then by 1767 there were only 4,802 people (12.8\%) from the Russian cavalry in their ranks.

Keywords: dragoons, soldiers, cavalry, line, nomads, Siberian Corps.

About the author: Puzanov Vladimir Dmitrievich, Dr. habil., Shadrinsky State Pedagogical University. Shadrinsk, Russia, alan1971@bk.ru

Военные реформы Петра I привели к формированию регулярных гарнизонных полков Сибири. В 1715-1720 гг. в Сибирской губернии были сформированы Санкт-Петербургский, Московский и Тобольский солдатские, и Сибирский гарнизонный драгунский. В 1727 г. солдатские полки были переименованы по районам формирования, в Тобольский, Енисейский, и Якутский. К 1726 г. в гарнизонных полках Сибирской губернии служили 
4991 человек [1, л. 273]. После экспедиции Бухольца 2000 солдат служили в крепостях по р. Иртыш [2, с. 138].

При Петре I в русской полевой армии были сформированы 34 драгунских полка. Кроме полевой армии, гарнизонные драгунские полки были сформированы в центрах губерний в стратегически важных городах Азове, Астрахани, Казани, Тобольске. В русской полевой армии к 1724 г. в 34 драгунских полках служили 41075 человек, и в 40 пехотных полках служили 58081 человек. Всего при Петре I в полевой армии имелось 74 полка, в которых служили 99159 человек [1, л. 264]. Кроме полевой армии в гарнизонных войсках России к 1725 г. служили 49 пехотных полка, драгунские полки Казанский, Астраханский, Воронежский, который был переведен из Азова и Сибирский, 2 отдельных эскадрона драгун Московский и Ярославский. Всего в гарнизонных войсках служили 70000 человек. В драгунском полку служили по штату 1182 чел., а в отдельном эскадроне 564 чел. К 1733 г. всего в гарнизонной драгунской кавалерии служили 5856 чел.

В 1730 г. русская регулярная армия составляла по штатному расписанию 227000 чел., однако в военных действиях могла использовать примерно половину этих сил [3, с. 107]. В 1730-1736 гг. в русской армии были сформированы 11 новых полков и 2 пехотных батальона. Характерно, что количество полков полевой армии сократились, а сформированы были новые драгунские и ландмилицкие полки для защиты пограничных линий на юге и востоке России. На Украинской и Ново-Закамской линиях формировались 14 ландмилицких полков. 18 мая 1734 г. были изданы указы об учреждении Уфимского и Оренбургского драгунских полков. 7 сентября 1736 г. началось формирование драгунского полка в Сибири [3, с. 180-181].

Во время башкирского восстания 1735-1741 гг. кочевники нападали на южные слободы Сибири. 25 августа 1736 г. власти Сибирской губернии писали в Сенат, что кочевники «людей бьют и берут в полон и отгоняют конские табуны и скот». Сибирский приказ для защиты слобод в Сибири предложил образовать 2 новых драгунских полка и 1 батальон пехоты. Главной проблемой в Сибири и в 1730-е гг. были отношения с Джунгарией. В 1736 г. власти Сибирского приказа писали, что в случае конфликта с контайшей джунгар, в Сибирь придется «полков немалый корпус». Контайша Джунгарии имел большое войско, «оной владелец весьма люден». Сибирский приказ сообщал, что если «полков армейских в Сибирскую губернию для предосторожности от владельца Галдан Черена прислано не будет, то надлежит с ним... искать союза» [4, л. 651-652].

7 сентября 1736 г. по доношению Сибирского приказа указом Сената в Сибири были учреждены 1 драгунский полк и 1 пехотный батальон. Главным источником личного состава новых частей стали сибирские служилые люди - «дворяне, казаки и их дети». В новые части Военной коллегией направлялись офицеры, отставленные из полевой армии, которые «гарнизонную службу снести могут» [5, с. 924].

Сибирский приказ составил расписание Новоучрежденного драгунского полка и Новоучрежденного батальона. В новые части Сибири для полного комплекта нужны были 1866 сибирских служилых людей, в драгунский полк 1133 чел., и в пехотный батальон 733 
чел., без офицеров. В сентябре 1737 г. в Сибирской губернии служили 9011 чел. дворян, детей боярских, казаков и прочих служилых людей. Кроме того, в Сибири было 4365 чел. рекрут, которых не брали в армию с 1732 г. Таким образом, по данным Сената, всего в Сибири имелось для формирования новых частей 13376 чел. [6, л. 678]. Однако к июню 1738 г. в Сибири в Новый драгунский полк зачислили только 496 служилых людей, и в Новый батальон пехоты - 370 чел., а всего 866 чел., которых послали на юг Сибири для защиты от набегов. [6, л. 1057-1058].

К середине XVIII в. обострились отношения России с джунгарами в районе округа Колывано-Воскресенских заводов. В 1740-1750 гг. Колывано-Воскресенские заводы стали важным источником пополнения бюджета Российской империи и главным центром добычи золота и серебра, которые давали возможность государству чеканить монету из своих российских драгоценных металлов. После взятия в казну у Акинфия Демидова КолываноВоскресенских заводов, с 1748 по 1759 г. заводы принесли, по данным правительства, «золота самого чистого» 89 пудов 14 фунтов на 962372 руб., серебра 2824 пуда 14 фунтов на 2231087 руб., а также меди 2396 пудов 15 фунтов на 15145 руб. Кроме того, на заводах имелась серебряная руда и медь ценой более на 100 тыс. рублей. Всего за 12 лет было получено с заводов металлов на 3313548 руб., из которых только 660000 руб. было употреблено на заводские расходы [7, с. 617].

24 августа 1744 г. в Сенат был вызван из Тулы Акинфий Демидов, который должен был сообщить по требованию сенаторов, по какой цене он покупает провиант для КолываноВоскресенских заводов, какие народы живут около заводов и до Телецкого озера и какие там есть поселения. На эти вопросы Демидов ответил, что на заводы привозят обыватели ржаную муку по цене 56 коп. пуд, а больше «показать он ничего не может за незнанием тамошних мест, понеже он Демидов на означенных своих заводах никогда не бывал» [8, с. 165].

Однако Колывано-Воскресенские заводы и земли около них стали причиной конфликта России с Джунгарией. 29 июля 1743 г. начальник Оренбургской экспедиции предложил «ради крепкой предосторожности от Зенгорцев и Казачей орды» отправить из Тобольска регулярные команды в форпосты Ишимской линии. 20 апреля 1744 г. в ответ на требование о присылке городских казаков и выписных казаков в Оренбургский край, власти Тобольска сообщили, что почти все служилые люди из ближайших к нему городов были посланы на Тобольные форпосты. В частности, по требованию полковника Павлуцкого «все наличные служилые люди Тюмени направлены туда без остатка» [9, л. 7]. Значительное число служилых людей имелось только на востоке Сибири - в Томске, Кузнецке и Красноярске, однако направить их оттуда в Оренбург было трудно по причине дальнего расстояния, кроме того, здесь они защищали земли от ойратов. По данным Тобольска, ойраты собирались в набег на казахов на р. Иртыша «от чего имеется великая опасность, дабы оные... легкомысленные и необузданные люди не учинили нападение на русские жилища» [9, л. 7]. В результате русские военные силы на юге были усилены - в Кузнецк отправилась рота солдат, а на Ишимские форпосты к Новоучрежденному драгунскому полку 272 служилых людей. 
28 июня 1744 г. в Усть-Каменогорскую крепость прибыли три урянхайца, подданные «зенгорского владельца», и сообщили, что правитель Джунгарии Галдан-Церен «имеет намерение собрать войско и пойти» на Усть-Каменогорскую, Семипалатную и Ямышевскую крепости и на Колыванский завод с войной. Весной 1744 г. к ним от правителя приезжал зайсан, приказавший «чтобы все урянхайцы были оружейны и исправны, нынешним летом будет поход на крепости». На вопрос: «отчего война?», посланцы ответили: «слышали они от старшин своих, завелся в новь на нашей земле на Чарыше завод и от того поднимается ссора» [10, л. 3].

Полковник Тимофей Зарин, командир Иртышской линии, требовал от Сибирской губернии прислать конницы, полагая, что ойраты «учинят за малолюдством верноподданным ея императорского величества народам разорение» [10, л. 5]. По данным Зарина, к 28 июля 1744 г. в Ямышевской крепости состояло 403 солдат и казаков, в Семипалатной крепости служили 304 солдат и казаков, в Усть-Каменогорской крепости служили только 141 чел., часть из которых отправлялась для экспедиции на озеро Ямыш [10, л. 3]. Таким образом, сил для отражения крупного набега кочевников в Иртышских крепостях не было.

22 мая 1744 г. указом императрицы Елизаветы Петровны из Сената в Военную коллегию было предписано «подать обстоятельную ведомость» и причем «немедленно»о состоянии войск и укреплений в Сибирской губернии - на верхнем Иртыше, по устье реки Оми и под городом Кузнецком - о «построенных российских крепостях», в каком они находятся состоянии, сколько в них артиллерии, аммуниции, и гарнизона - регулярных и нерегулярных войск. Коллегия должна была также сообщить о состоянии гарнизонных полков в Сибирской губернии - сколько в них состоит людей и их службах «и куда они особливо употребляются», а также нерегулярных войск - «а именно дворян, казаков и прочих тому подобных» [11, л. 2].

Военная коллегия сообщила, что в Сибири состояли гарнизонные полки - конные Сибирский и Новоучрежденный драгунские полки и пехота - Тобольский, Енисейский и Якутский полки и Новоучрежденный батальон. В справке специально отмечалось, что Якутский полк состоит на рубеже с Китаем - далеко от р. Иртыш. Кроме того, в городах Западной Сибири близких к р. Иртыш служили, по данным Тобольска, только 2180 служилых людей «старых служб». Так, в Тобольске имелось 777 чел. русских служилых людей и татар, на Верхотурье - 90 чел., в Туринске - 45 чел., в Таре 347 чел., в Пелыме 20 чел., в Кузнецке - 249 чел., в Томске - 367 чел., в Нарыме - 80 чел., в Енисейске 205 чел.

По рапорту из Сибирской губернии от 28 февраля 1744 г. в Сибирском и Новоучрежденном драгунском полках, Тобольском и Енисейском пехотном полках и в Новоучрежденном батальоне по данным с 1 сентября 1743 г. по 1 января 1744 г. служили 5809 чел., из которых 3010 чел. были командированы на юг - в Иртышские крепости и в крепости Оренбургской губернии. В результате «при команде» осталось только 2799 чел. 2704 чел. здоровых и 84 больных, 11 солдат состояли под арестом. Для полного комплекта надо было прислать еще 80 чел. солдат и унтер-офицеров. 
Указом Сената от 14 июня 1725 г. было разрешено брать «для употребления» на заводские работы рекрутов с приписных к заводам деревень Казанской и Сибирской губерний. 6 марта 1744 г. Сенат приказал оставить для защиты заводов, собранных в 17421743 гг. крестьян из приписных к заводам деревень «потребное число» [11, л. 5].

11 сентября 1744 г. Сенат рассмотрел вопрос защиты Сибири от возможного нападения джунгар, и решил, что сил 5 гарнизонных полков и 1 батальона, крайне мало для большой территории Сибири. В край по указу Елизаветы Петровны и по «определению» Сената было приказано «немедленно отправить» 3 драгунских полка из Оренбургской губернии, 2 полка Низового корпуса, выведенных из Персии, и при нужде еще 3 драгунских полка, чтобы «чтобы для такого сильного неприятеля всегда содержать особливый военный корпус». В сибирских городах Сенат решил собрать 6000 чел. и зачислить их в казаки, 3000 чел. из них отправив на рубеж с Джунгарией. Сенат предложил сформировать в Сибири еще 2 пехотных полка. Чтобы найти средства - 85760 рублей для содержания новых военных частей и казаков Сибири, Сенат даже предложил императрице распустить полк Конной гвардии, который содержался на доходы Сибири, направив его личный состав в другие полки [8, c. $180-185]$.

По указу Елизаветы Петровны 25 октября 1744 г. на Иртышскую линию были командированы Олонецкий, Вологодский и Луцкий полевые драгунские полки и 1000 яицких казаков из войск, находившихся в Оренбургской губернии. Позднее в Сибирь были отправлены Ширванский и Нашебургский пехотные полки, которые были сформированы Петром I в Низовом корпусе и служили на Кавказе в бывших провинциях Персии. Полки имели опыт войны с кочевыми войсками. В 1738 г. Ширванский и Нашебургский пехотные полки под командой фельдмаршала Ласси воевали с турками, а Вологодский драгунский полк боролся с башкирами на Закамской линии [12, л. 3].

По указу Сената от 29 сентября 1744 г. все военные силы Сибири были подчинены главному командиру Сибирского корпуса. Военная коллегия назначила командиром генералмайора Христиана Киндермана [13]. В октябре 1744 г. на восток были срочно отправлены для руководства Сибирским корпусом генерал Киндерман и бригадир Юрлов. 11 октября 1744 г. в сенатскую контору был вызван генерал-майор Киндерман, где ему было сообщено о его назначении «к команде в Сибирь» [8, с. 228]. Генерал Христиан Киндерман был одним из многих европейцев служивших в Российской империи, поступивших на службу России при Петре I и отдавших свои силы и знания новой родине. В 1715 г. Христиан Киндерман поступил в российскую службу, в 1726 г. он служил майором пехотного полка фон Гагена, затем Выборгского драгунского полка, а в апреле 1730 г. подполковником Ярославского драгунского полка, с 1733 г. полковником Ростовского драгунского полка. В 1734-1735 г. Киндерман служил в Дербенте, в 1736 г. участвовал в войне с Турцией и служил при взятии Азова под командой знаменитого полководца фельдмаршала Петра Ласси. В 1738 г. стал командиром Низовского пехотного полка. Христиан Киндерман участвовал в боях армии П. Ласси в Финляндии со шведами и после первой крупной победы русских войск над корпусом Врангеля в 5 тыс. чел. 3 сентября 1741 г., был отмечен среди других отличившихся генералов 
и офицеров. Именно во время войны с Швецией 11 сентября 1741 г. Х. Киндерман получил чин генерал-майора. В 1742 г. Киндерман служил под командой П. Ласси, командуя русским отрядом на галерах в армии, собранной в мае под Выборгом, и принял участие в последующих событиях войны [14, с. 927].

Из Сибири в это время приходили новые известия об ойратах. 16 ноября 1744 г. в Сенате обсуждался рапорт из Тобольска от 26 октября. 29 сентября урянхайцы на охоте сказали солдату Тюрину из команды полковника Зарина, что Галдан-Церен собрал 4 тысячи ойратов и собирается идти в поход на казахов. Ранее распространялись слухи о походе ойратов с казахами в Сибирь. Сибирская канцелярия приказала Зарину «всякими возможными способы» разведать, что же будет делать владелец ойратов [8, с. 255].

В ноябре 1744 г. полковник Олонецкого полка Крафт с 3 армейскими драгунскими полками из Оренбургской губернии «немедленно и прямым трактом» был отправлен северным путем - на Кунгур, а затем в Екатеринбургский уезд, а оттуда в Тюменский уезд Сибирской губернии. Однако Крафт пошел по направлению к Казани, дав крюк в 400 верст пути.

По данным Сибирской губернской канцелярии, осенью 1744 г. до прихода полков из Тобольска в 5 крепостях и 7 форпостах на р. Иртыш служили 1366 чел. «регулярной и нерегулярной команды». Кроме того, из городов Сибири было выслано в крепости по р. Иртыш и на форпосты Кузнецкого уезда 568 казаков, русских и татар, дворян и детей боярских. 8 сентября на сибирские форпосты прибыл драгунский полк, посланный из крепостей Оренбургской губернии по требованию властей Сибирской губернии. Полк получил приказание занять тобольные и ишимские форпосты недавно построенной Ишимской линии [8, с. 277].

Осенью из Сибири начали поступать уже совсем другие известия о намерениях контайши. 14 октября 1744 г. полковник Зарин из Ямышевской крепости сообщил рапортом в Тобольск, что томский купец Мельников, ездивший в Джунгарию, видел контайшу ГалданЦерена «в добром здоровье», причем он кочует «с малыми людьми» и не собирается идти в военный поход. К российским людям Галдан-Церен, как сказал купец, «весьма был добр», не обижал и даже дал Мельникову конвой для проезда в русские владения. Зарин писал, что в крепостях на р. Иртыш «состоит все благополучно» и нет никаких известий о набегах [8, c. 256].

11 января 1745 г. Сенат получил сообщение сибирской губернской канцелярии, от 10 декабря 1744 г. которая сообщала, что по известиям, полученным из Ямышевской крепости, ойраты не собирались воевать в Сибири. Посланные на р. Иртыш драгунские полки в Тобольске было решено оставить в слободах на юге Тарского уезда до Омской крепости, где было больше продовольствия, так как в Иртышские крепости еще не был завезен провиант. Отправленный из Тобольска в крепости на р. Иртыш пехотный полк и служилые люди с полковником Павлуцким продолжали свой поход на восток [8, с. 299].

30 декабря 1744 г. сибирская губернская канцелярия направила в Сенат новый рапорт, на основании рапортов, полученных ранее в Тобольске из Иртышских крепостей, согласно 
которому на р. Иртыш не было нападений кочевников «и состоит все благополучно». Из Джунгарии в разные Иртышские крепости прибыли 96 торговцев с товарами, которые в расспросе сообщили, что контайша Галдан-Церен кочует на р. Или в месяце пути от УстьКаменогорской крепости и не собирается с кем-либо воевать [8, с. 310].

В 1745 г. 5 полевых полков были переведены в Сибирь. В июле 1745 г. Олонецкий и Вологодский драгунские полки, Ширванский пехотный полк и яицкая команда казаков прибыли в Омскую крепость из Ишимского дистрикта. [8, с. 537]. В результате на востоке России возник особый Сибирский корпус из 5 полевых полков, гарнизонных полков и казаков на линиях. Посылка корпуса в Сибирь протекала в сложных внешнеполитических условиях. В это время Россия фактически вступила в войну за Австрийское наследство, поддержав старую союзницу - Австрию, оказывая давление на ее соперников. В 1746-1748 гг. вся полевая русская армия была собрана в Прибалтике, откуда в 1748 г. была послана армия под командой генерал-аншефа В. Н. Репнина на р. Рейн.

В сентябре 1745 г. контайша Галдан-Церен умер. Как стало известно от ойратов, прибывших в Ямышевскую крепость с купеческим караваном, в январе 1745 г. во время болезни Галдан-Церен приказал знати «с Россией и с китайцами войны отнюдь не держать и жить в тишине и с прочими ордами». Контайша сказал знатным людям ойратов, чтобы русские не строили крепостей к югу от Усть-Каменогорской крепости. Если же они будут строить новые крепости между уже построенными крепостями, то «от тех де утеснения не имеется и не мешают». Этот совет контайши был принят знатью «за благо», простой народ также «все покою рады и тишины желают». Однако, по русским данным, между ойратами было «не согласно». Одна партия хотела отдать власть старшему сыну от наложницы ЛамеДоржи «ибо де он смысл и остроту к правлению их владения имеет», а другая желала правления младшего но законного сына Бичаган-Цагана [8, с. 610, 625].

20 мая 1746 г. Сенат запросил Военную коллегию: «есть ли какая опасность в Сибири от зенгорской стороны и можно ли команду яицких казаков отпустить из Сибири в Оренбургскую губернию, а донских казаков оттуда в свои дома, чтобы защищать свою территорию?». 1000 яицких казаков была отправлена в Сибирь 1744-1745, 1000 казаков содержала форпосты на низовьях р. Яик, в домах оставалась только 1000 казаков [8, с. 669]. Коллегия предложила отпустить казаков из Сибири, однако окончательное решение отдавала Сенату. Сенат решил вернуть казаков в Оренбургскую губернию [8, с. 679]. 3 июня Военная коллегия сообщила, «что к Сибири с зенгорской стороны никакой дальней опасности нет. Галдан-Церен умер, а его сын прислал в Тобольск лист «что он с Россией в дружбе пребывает и купечество по-прежнему отправлять хочет».

Наиболее опасными районами в 40-50 гг. XVIII в. являлись крепости по р. Иртышу и Кузнецкого края, так как данные территории оставались спорными с Джунгарским ханством, так и не признавшим власть Российской империи над этими землями. В период зимы у крепостей имели место столкновения с большими группами казахов, постоянно пытавшимися перейти на русский берег р. Иртыша для зимовки. Так зимой 1755 г. к реке Иртышу прикочевали 300 - 500 вооруженных казахов [15, л. 2]. 
По данным Х. Киндермана, к 1750 г. юг Сибири на 2728 верст от Тобольного форпоста на р. Тобол до г. Кузнецка, защищали только около 10000 чел. регулярных и нерегулярных войск. Генерал отмечал, что многочисленные кочевые народы могут создать серьезную угрозу для русских владений, совершив набег на Сибирь [16, с. 235]. К 1751 г. в Сибирской губернии имелось на службе 4764 казака - 4271 русских и 493 служилых татар [17, л. 1].

В 1750 г. генерал-майор Беер просил прислать на Колыванскую линию яицких или донских казаков и 1000 сербских гусар [18, с. 42].

К 1751 г., по данным Х. Киндермана, Сибирский драгунский полк занимал район Иртышских крепостей, а Новоучрежденный драгунский полк стоял на Колыванской и Кузнецкой линии, и в Красноярском уезде [17, л. 3]. В это время в Сибири началось строительство Новой Ишимской линии, соединявшей русские крепости по р. Иртыш и линии Оренбургской губернии. В 1752 г. Х. Киндерман определил, что в крепости Новой Ишимской линии необходимо содержать 3642 чел. - 1290 регулярных и 2352 нерегулярных [16, с. 451].

В Сибири генерал Х. Киндерман умер и 31 июля 1752 г. в правление команды Сибирским корпусом вступил бригадир Крафт. 1 августа 1752 г. Военная коллегия в ответ на указ Сенат, об определении на место генерал-майора Киндермана «надежной персоны» приказала до особого указа возложить команду над армейскими и гарнизонными полками и служилыми людьми Сибири «обретающемуся там» бригадиру Крафту [16, с. 659, 701].

В 1750-е гг. в Европе началась дипломатическая и военная подготовка новой большой войны «великих держав». Елизавета Петровна начала готовить полевую армию для войны в Европе. В 1752 г. Военная коллегия по расписанию полевой армии решила вывести 3 драгунских полевых полка из Сибири в Казанскую губернию на винтер-квартиры. 24 июня 1753 г. Военная коллегия приказала во исполнение императорского указа от 9 июня 1753 г. перевести из Сибири в Казань 2 пехотных полка - Ширванский и Нашебургский. 4 августа 1753 г. Крафт рапортовал в Военную коллегию, что это невозможно в настоящее время, так как оба полка были разбиты на небольшие отряды, которые находились «в отдалении от Тобольска» [19, л. 4]. Ширванский стоял в Иртышских крепостях, за 1500 верст от Тобольска, а Нашебургский - на Новой линии в крепостях, на работах, и в конвоях с провиантом.

Крафт сообщал также, что 3 драгунских полевых полка в это время находились на Новой линии, «знатная команда» в разъездах между строившихся укреплений, а другие стояли на старых форпостах, не терявших своего значения до окончания строительства Новой линии. Крафт предложил направить на Иртышскую линию на смену Ширванскому полку команду в 1000 чел., собранную из 3 драгунских полков, «ибо по той обширной линии одному Сибирского гарнизона Сибирскому гарнизонному полку обнять и содержать никак невозможно» $[19$, л. 5]. Вторая команда драгун в 1000 чел. должна была остаться на Новой линии. 25 августа 1753 г. Военная коллегия приказала Крафту как можно быстрее собрать всех командированных из полков и направить их в Казань «без всякого продолжения», закрыв линии имеющимися полевыми драгунскими и гарнизонными драгунскими полками. 
В 30-50 гг. XVIII в. количество полевых драгунских полков Российской империи уменьшилось до 20, за счет формирования из них кирасирских, а позднее конногренадерских полков, которые готовились, прежде всего, для борьбы с тяжелой кавалерией европейских великих держав. К середине XVIII в. драгунская кавалерия находилась в кризисе, в результате из 20 драгунских полков Военная коллегия смогла направить на участие в кампаниях Семилетней войны только 3 полка. Главную роль в войне сыграли кирасирские, конногренадерские и гусарские полки.

В марте 1756 г. Военная коллегия сообщила в Конференцию, что в русской армии состоят 3 кирасирских, 29 драгунских и 46 пехотных всего 78 армейских полков, в которых служат 172440 чел. [20, с. 32-35]. 6 апреля 1756 г. Конференция при дворе ее императорского величества назначила к военным действиям в Европе армию в 130000 чел., из них 110000 чел. регулярных и 20000 чел. нерегулярных. При этом часть войск оставалась в губерниях, в Москве служили 4 полка Навагинской, Московский гарнизонный, а также выведенные из Сибири Нашебургский и Ширванский, которые Конференция приказала «содержать в готовности, дабы ежели нужда будет в поход выступить могли» поддерживая главную армию С. Апраксина. Всего в империи служили кроме гвардии и нерегулярных войск 112 полевых, гарнизонных и ландмилицких полков, 2 эскадрона и 5 батальонов, а в них 161795 чел. [20, с. 45-49].

Комиссия Военной коллегии в 1756 г. сформировала 6 конногренадерских полков, которые наряду с кирасирскими должны были стать в сражениях войны ударной силой русской армии. Военная коллегия планировала в период формирования новых полков тяжелой кавалерии раскассировать два полевых драгунских полка - Олонецкий и Луцкий из трех, командированных в Сибирь. Личный состав полков Военная коллегия собиралась направить частично в новые кавалерийские полки, a частично отдать в «новопрожектируемые губернские полки» [21, л. 1]. Конференция назначила к формированию кирасирских и конных гренадерских полков Олонецкий и Луцкий драгунские полки, однако 6 апреля 1756 г. в протоколе отметила, что «...при нынешних обстоятельствах и тамошнюю сторону совсем войсками обнажить не надлежит». Конференция в итоге оставила эти 2 полка, которые остались «сверх нового положения излишними... впредь не касовать, но содержать их в нынешнем состоянии и с нынешним жалованьем на воинской службе» $[20$, с. 49$]$.

Позднее 16 мая 1756 г., отметив наличие ряда сложных внешнеполитических проблем на юге Сибири, Военная коллегия решила, что теперь восточные провинции «совсем войсками обнажать не надлежит». Количество полевых драгунских полков Военная коллегия уменьшила с 20 до 18, но 2 полка Сибирского корпуса не раскассировали, а временно оставили излишними «сверх нового положения». В эти полки Военная коллегия решила не направлять новых рекрутов, а Вологодский драгунский полк комплектовать из состава 2 «излишних полков» [21, л. 2]. Это решение позволяло не направлять в Сибирь рекрут из Европейской России, чтобы «чаемого от того немалого труда избегнуть было можно». В результате этого решения Военная коллегия все 3 полевых драгунских полка, имевшихся в 
Сибири, остались без пополнений из Европейской России. К 1765 г. по данным Шпрингера некомплект в них составил примерно 1000 чел. [22, л. 28]. В итоге во время Семилетней войны число полевых драгунских частей России уменьшилось в 3 раза и к 1763 г. составляло всего 7 полков. В результате, если в 1754 г. драгуны составляли 36627 человек (92,6 \%), то к 1767 г. в их рядах насчитывалось только 4802 человек (12,8 \%) от русской кавалерии.

К 1755 г. в Сибирской губернии остались 3 полевых драгунских полка Олонецкий, Вологодский и Луцкий, всего 3789 человек, и 2 гарнизонных драгунских Сибирский и Новоучрежденный, всего 2238 человек. Кроме того, в губернии служили 3 пехотных гарнизонных Тобольский, Енисейский, Якутский и Новоучрежденный батальон в 4420 человек. Всего в Сибири в 8 полках и батальоне служили 10447 человек [23, л. 2].

После конца Семилетней войны полки, выведенные из Сибири служили в Европейской России. К 1763 г. Нашебургский полк состоял в Санкт-Петербургской дивизии, а Ширванский полк - в Московской дивизии [24, с. 27].

\section{Литература}

1. Российский государственный архив древних актов (РГАДА). Ф. 9. Оп. 1. Д. 29.

2. Памятники сибирской истории XVIII в. / ред. А.И. Тимофеев. СПб.: тип. М-ва внутр. дел, Кн. 1. 1882. XXXII, 551, [1] с.

3. Петрухинцев Н.Н. Царствование Анны Иоанновны: формирование внутриполитического курса и судьбы армии и флота, 1730-1735 г. СПб.: Алетейя, 2001. $352 \mathrm{c}$.

4. РГАДА. Ф. 248. ОП. 3. Кн. 135.

5. Полное собрание законов Российской Империи с 1649 г. Собрание 1. Т. 9 (с 1733 по 1736 г.). СПб.: Тип. ІІ Отделения Собственной Его Императорского Величества Канцелярии, 1830. $1028 \mathrm{c}$.

6. РГАДА. Ф. 248. ОП. 3. Кн. 134.

7. Полное собрание законов Российской империи с 1649 г. Соб. 1. Т. 15 (с 1758 по 1762 г.). СПб.: Тип. ІІ Отделения Собственной Его Императорского Величества Канцелярии, 1830. $1051 \mathrm{c}$.

8. Сенатский архив. Т. 6. Протоколы Правительствующего сената 1744-1746 гг. СПб.: Сенат. тип., 1893. 802, 38 с.

9. Государственный архив Омской области (ГАОО). Ф. 366. Оп. 1. Д. 5.

10. РГАДА. Ф. 24. ОП. 1. Д. 29.

11. Российский государственный военно-исторический архив (РГВИА). Ф. 20. Оп. 1/47. Д. 261.

12. РГАДА. Ф. 20. ОП. 1. Д. 138.

13. РГАДА. ф. 248. Оп. 4. Кн. 180.

14. Полное собрание законов Российской империи с 1649 г. Соб. 1. Т. 11 (с 1740 по 1743 г.). СПб.: Тип. ІІ Отделения Собственной Его Императорского Величества Канцелярии, $1830.992 \mathrm{c}$. 
15. ГАОО. Ф. 366. Оп. 1. Д. 29.

16. Сенатский архив. Т. 8. Протоколы Правительствующего сената 1750, 1751 и 1752 гг. СПб.: Сенат. тип., 1897. 746, 32 с.

17. ГАОО. Ф. 366. Оп. 1. Д. 17.

18. Материалы для истории Сибири / собр. Г.Н. Потанин. М.: ИмП. О-во истории и древностей российских при Моск. ун-те, 1867. 324 с.

19. ГАОО. Ф. 366. Оп. 1. Д. 22

20. Семилетняя война. Материалы о действиях русской армии и флота в 1756-1762 гг. / под ред. М.Н. Коробкова. М.: Воениздат, 1948. 916 с.

21. РГВИА. Ф. 23. Оп. 1/121. Д. 796.

22. РГВИА. Ф. 23. Оп. 1/121. Д. 937.

23. ГАОО. Ф. 366. Оп. 1. Д. 24.

24. Лебедев А. Русская армия в начале правления Екатерины II. Материалы для русской военной истории. М.: Унив. тип., 1899. VI. 114 с.

\section{References}

1. Rossiiskii gosudarstvennyi arkhiv drevnikh aktov (RGADA). F. 9. Op. 1. D. 29. (In Russian).

2. Pamyatniki sibirskoi istorii XVIII v. (1882). St. Petersburg. (In Russian).

3. Petrukhintsev, N.N. (2001). Tsarstvovanie Anny Ioannovny: formirovanie vnutripoliticheskogo kursa i sud'by armii i flota, 1730-1735 g. St. Petersburg. (In Russian).

4. RGADA. F. 248. Op. 3. Kn. 135. (In Russian).

5. Polnoe sobranie zakonov Rossiiskoi Imperii s 1649 g. Sobranie 1.9 (1733-1736) (1830). St. Petersburg. (In Russian).

6. RGADA. F. 248. Op. 3. Kn. 134. (In Russian).

7. Polnoe sobranie zakonov Rossiiskoi imperii s 1649 g. Sob. 1.15 (1758-1762) (1830). St. Petersburg. (In Russian).

8. Senatskii arkhiv (1893). 6. In Protokoly Pravitel'stvuyushchego senata 1744-1746 gg. St. Petersburg. (In Russian).

9. Gosudarstvennyi arkhiv Omskoi oblasti (GAOO). F. 366. Op. 1. D. 5. (In Russian).

10. RGADA. F. 24. Op. 1. D. 29. (In Russian).

11. Rossiiskii gosudarstvennyi voenno-istoricheskii arkhiv (RGVIA). F. 20. Op. 1/47. D. 261. (In Russian).

12. RGADA. F. 20. Op. 1. D. 138. (In Russian).

13. RGADA. f. 248. Op. 4. Kn. 180. (In Russian).

14. Polnoe sobranie zakonov Rossiiskoi imperii s 1649 g. Sob. 1. T. 11 (1740-1743) (1830). St. Petersburg. (In Russian).

15. GAOO. F. 366. Op. 1. D. 29.

16. Senatskii arkhiv. T. 8. Protokoly Pravitel'stvuyushchego senata 1750, 1751 i 1752 gg. (1897). St. Petersburg. (In Russian). 
17. GAOO. F. 366. Op. 1. D. 17. (In Russian).

18. Materialy dlya istorii Sibiri (1867). Moscow. (In Russian).

19. GAOO. F. 366. Op. 1. D. 22. (In Russian).

20. Semiletnyaya voina (1948). In Materialy o deistviyakh russkoi armii i flota v 1756-1762 gg. Moscow. (In Russian).

21. RGVIA. F. 23. Op. 1/121. D. 796. (In Russian).

22. RGVIA. F. 23. Op. 1/121. D. 937. (In Russian).

23. GAOO. F. 366. Op. 1. D. 24. (In Russian).

24. Lebedev, A. (1899). Russkaya armiya v nachale pravleniya Ekateriny II. In Materialy dlya russkoi voennoi istorii, Moscow. (In Russian).

Пузанов В.Д. Русская армия в Сибири в 30-50 годы XVIII в. // Вестник Нижневартовского государственного университета. 2021. № 3(55). С. 84-95. https://doi.org/10.36906/2311-4444/21-3/08

Puzanov, V.D. (2021). The Russian army in Siberia in the 30-50 years of the XVIII century. Bulletin of Nizhnevartovsk State University. (3(55)). 84-95. (In Russian). https://doi.org/10.36906/2311-4444/21-3/08 